\title{
The impact of STEAM integration on preservice teachers' disposition and knowledge
}

\author{
Shuhua An \\ Department of Teacher Education, California State University, Long Beach, \\ Long Beach, California, USA
}

Received 16 January 2020

Revised 10 March 2020

Accepted 14 March 2020

\begin{abstract}
Purpose - This study intended to provide such an opportunity to preservice teachers with a project-based learning (PBL) approach and an inquiry-based pedagogy to engage them in learning science, technology, engineering and mathematics (STEM) knowledge and skills of integration with adding an art component to STEM as science, technology, engineering, arts and mathematics (STEAM) for K-8 children, and developing their own STEAM tasks. The purpose of this project was to explore how STEAM integration in mathematics methods courses influenced K- 8 preservice teachers' disposition and knowledge of STEAM integration.

Design/methodology/approach - This project used a mixed-research design in data collection and analysis to examine the effects of using the STEAM integration on preservice teachers' knowledge and disposition. The preservice teachers in two EDEL 462 classes in Spring 2019 participated in STEAM learning and development in the inquiry process of four steps of STEAM integration. Data collection includes the pre- and postquestionnaires on teachers' knowledge and disposition.

Findings - The results in this study show that the STEAM integration in the mathematics methods courses engaged preservice teachers in four steps of the inquiry process of connection, collaboration, communication and evaluation for STEAM integration using PBL approach. The preservice teachers not only enhanced their disposition in attitude and confidence but also enhanced their knowledge of STEAM integration.

Research limitations/implications - The following conclusions can be drawn from the present study that integrating STEAM components in mathematics methods fosters preservice teachers' creativity, connection, communication, application and teamwork skills, and importantly, it enhances K-8 preservice teachers' productive dispositions and knowledge in STEAM integration.

Practical implications - The results of this study indicate that using math methods courses to engage preservice teachers in learning STEAM integration and designing authentic STEAM tasks in four steps enhanced preservice teachers' attitude and confidence that significantly related to their knowledge of STEAM integration.

Originality/value - These findings have significant implications for the understanding of how to prepare future teachers in STEAM integration in higher education.
\end{abstract}

Keywords STEAM integration, Preservice teachers, Teachers' disposition, Teachers' knowledge,

Mathematics education

Paper type Research paper

\section{Introduction}

In today's digital era, rapid development of new technology has a profound impact on the ways we teach and children learn. The International Society for Technology in Education (ISTE) (2017) calls for major changes in education by rethinking education, adapting to a constantly changing technological landscape and preparing students to enter an increasingly global economy. To make changes, educators need to collaborate with colleagues to improve

(C) Shuhua An. Published in Journal of Research in Innovative Teaching \& Learning. Published by Emerald Publishing Limited. This article is published under the Creative Commons Attribution (CC BY 4.0) licence. Anyone may reproduce, distribute, translate and create derivative works of this article (for both commercial and non-commercial purposes), subject to full attribution to the original publication and authors. The full terms of this licence may be seen at http://creativecommons.org/ licences/by/4.0/legalcode

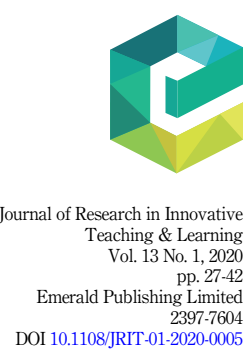


JRIT

13,1

practice, discover and share resources and ideas, and solve problems (ISTE, 2017). However, teachers' decisions in using technology in the classroom are often influenced by their own knowledge and level of confidence (Wu and An, 2015). To equip classroom teachers with solid knowledge and skills and strong confidence in using technology, it is important for teacher educators to "empower connected learners in a connected world" (ISTE, 2017). One of the central approaches to empower teachers is to prepare them to integrate science, technology, engineering and mathematics (STEM) in their teaching in pre-K-12 education (An, 2017; Burton, 2019; Bybee, 2010; Carnevale et al., 2011; Tsupros et al., 2009). This integration develops creativity and innovation, communication and collaboration, research and information fluency, critical thinking, problem-solving, decision-making, digital citizenship and technology operators and concept (ISTE, 2007). However, as generalists, elementary preservice teachers often enter teacher education programs with less confidence and interest in teaching STEM subjects (Weiss et al., 2001). Research has suggested that preservice teachers should have an opportunity with earlier and more interdisciplinary teaching experiences in order to better develop their interdisciplinary pedagogical content knowledge (PCK) earlier in their careers (An, 2017; An and Tillman, 2018; Doering et al., 2009).

This study intended to provide such an opportunity to preservice teachers with a projectbased learning (PBL) approach and an inquiry-based pedagogy to engage them in learning STEM knowledge and skills of integration with adding the arts component to STEM as science, technology, engineering, arts and mathematics (STEAM) for K-8 children, and developing their own STEAM tasks. Integrating arts into STEM can make lesson outcomes more successful and interesting, and it can also promote powerful and inspired creative thinking in the teaching and learning process (Sousa and Pilecki, 2013). However, in current research, little is known about how STEAM integration in teacher education program influences preservice teachers' disposition and knowledge.

The purpose of this project was to explore how STEAM integration in mathematics methods courses influenced K-8 preservice teachers' disposition and knowledge of STEAM integration. This study aimed at investigating the following research questions:

(1) Is there any significant differences in K-8 preservice teachers' disposition toward math teaching and STEAM integration between the pre- and postquestionnaires?

(2) What is the relationship between preservice teachers' disposition and knowledge of STEAM integration?

(3) What are the characteristics of the experience in learning from STEAM integration by preservice teachers?

(4) What are the common interesting topics used by preservice teachers for STEAM integration at $\mathrm{K}-2,3-5$ and $6-8$ levels?

(5) How have the Next Generation Science Standards (NGSS) connected with the Common Core State Standards for Mathematical (CCSSM) standards through STEAM tasks by preservice teachers?

(6) How have the NGSS Science and Engineering Practices (SEP) standards connected with the CCSSMP standards through STEAM tasks by preservice teachers?

\section{Theoretical framework}

\section{Importance of STEAM education}

In recent years, there has been an increasing interest in multidisciplinary integration in education. Many organizations and researchers consider multidisciplinary integration as a promising approach in teaching and teacher education (An, 2017; Burton, 2019). For example, 
various professional organizations, such as National Academy of Engineering and National Research Council (NRC) (2014), National Council of Teachers of Mathematics (2014), NGSS Lead States (2013), National Research Council $(1989,2011)$ and National Science Foundation (2010) have stated their position and support for the integration of STEM in K-12 teaching and learning. According to the National Academies of Sciences, Engineering, and Medicine (2016), the future competitiveness of the United States in an increasingly interconnected global economy depends on the nation fostering a workforce with strong capabilities and skills in STEM areas. STEM knowledge and skills enable both individual opportunity and national competitiveness, and the nation needs to develop ways of ensuring access to highquality education and training experiences for all students at all levels and for all workers at all career stages. STEM education also develops students' interconnected skills of problemsolving, adaptability, complex communication, self- management and social skills (NRC, 2011).

In recent decades, various international assessments, such as PISA and TIMMS, show that US student achievement in mathematics and science still lags considerably behind other industrialized nations (National Center for Education Statistics, 2015a, b, 2018). At the National level, math, science and reading achievement levels of California's public school students in grades 4 and 8 on the National Assessment of Educational Progress have been below the national level in recent years (National Center for Education Statistics, 2018). Locally, according to the 2018 California Assessment of Student Performance and Progress (CAASPP), statewide in all grades, only about $38 \%$ of students met or exceeded the mathematics standards (California Department of Education, 2019a, b). The results of students' low performance in CAASPP show great challenges in teaching and learning new CCSSM.

To improve students' mathematics learning, there is an urgent need to develop innovative teaching approaches to engage them in authentic learning experiences (NCTM, 2014) with sense making and using appropriate tools in real world application as addressed in the CCSSM [National Governors Association Center for Best Practices (NGACBP), Council of Chief State School Officers (CCSSO), 2010]. To be successful in implementing state standards and improve student learning, the STEM Task Force (2017) states that California's efforts to improve schools and raise student achievement must include advancing our students' understanding of STEM. Students learn to become problem solvers, innovators, creators and collaborators and go on to fill the critical pipeline of engineers, scientists and innovators so essential to the future of California and the nation through STEM education (California Department of Education, 2017).

\section{Needs for teacher learning}

To support children's STEAM learning, classroom teachers at K-8 need to be trained with a set of rich knowledge and skills of STEAM integration so that they can use the integrated approach in teaching. However, there is a scarcity of research that has examined the STEM preparation of teachers (Brown, 2012; Scott, 2012).

Currently, the increasing growth of STEAM education poses challenges in teaching and learning. The main challenge lies in developing teachers' knowledge and pedagogy in instruction integration (An, 2017; Koehler and Mishra, 2009). This challenge, in part, is that elementary teachers lack meaningful STEM experiences and often provide poor instruction to their students (DiFrancesca et al., 2014). The challenge is also because students are more technologically advanced than many teachers are today, putting instructors at a decided disadvantage in the classroom (Chen, 2015). In addition, as indicated by NCTM (2014), too many teachers have limited access to the instructional materials, tools and technology they need. Therefore, to support children's STEM learning using an integrated approach, 
JRIT

13,1

preservice teachers need to be trained with a different type of knowledge of pedagogy and understanding the connections across content areas (An, 2017). They also need rich resources and instructional materials with an opportunity of positive STEM experiences to be success in STEM integration (Burton, 2019; Nadelson and Seifert, 2013).

Given the features of the fast development of technology, a crucial element of teacher professional development programs on STEAM is not only developing students "creativity and innovation; communication and collaboration; research and information fluency; critical thinking, problem solving, and decision making; digital citizenship; and technology operators and concept" (ISTE, 2007, p. 12) but also fostering students' productive disposition (NRC, 2001) to get students excited about learning so teachers will "empower connected learners in a connected world" (ISTE, 2017). Teacher professional development programs need to support teachers to develop their competency in technology that equips teachers with the skills needed to integrate new technology tools into their classrooms and keep up with their student learning (Koehler and Mishra, 2009; ISTE, 2017). Research studies recommend teachers form the teacher design team to work in professional groups redesigning educational material for curriculum design programs (Binkhorst et al., 2015). It is also important to build the confidence and competency of teachers to put the technology and STEAM-related standards for students and educators into practice (ISTE, 2018).

\section{Approaches in STEM education}

Central to the interdisciplinary approach is how to effectively integrate subject areas of STEAM. Many STEM programs do not fully integrate STEM subject areas and the results do not provide substantial science and mathematical learning (An, 2017; Shaughnessy, 2013). According to An (2017), it is critical for teacher education program to providing experiences and mentorship for preservice teachers to develop their ability in teaching multiple subject areas effectively within one lesson in their interdisciplinary teaching. PBL has been an effective approach in STEM integration (Han et al., 2015). PBL also increases students' engagement, critical reasoning, collaboration and holistic approach. Essentially, PBL is an instructional "learner-centered approach that empowers learners to conduct research, integrate theory and practice, and apply knowledge and skills to develop a viable solution to a defined problem” (Savery, 2006, p. 12).

Belliveau (2007) indicated that preservice teachers need to try new ideas, engage in inquiry-based teaching and learning within a collaborative and supportive community in integration. The collaborative nature of the STEAM integration process allows for enhanced communication and consideration (Park et al., 2016). Teachers should work together collaboratively to analyze their curriculum, design and develop new curriculum, and implement and evaluate their shared curriculum (Huizinga et al., 2015). Research has also suggested that preservice teachers need to have experiences to fully visualize their place in authentic classrooms with strategies and pedagogy learned from coursework (Abell, 2006; Burton, 2019). The effective strategies and pedagogy to the integration are associated with positive student learning outcomes including, but not limited to, communication, teamwork skills, decision-making, critical thinking and deeper learning, content mastery, engagement and enjoyment of learning, empathy, resilience and the ability to apply knowledge in realworld settings (National Academy of Science, 2018).

One of key integration processes is engineering design process that provides students a foundation in engineering design, which allows them to better engage in and aspire to solve the major societal and environmental challenges they will face in the decades ahead (NGSS Lead States, 2013). In the engineering design process, teachers need to engage students in formalizing problem-solving, and then defining a problem using criteria for success and constraints of possible solutions. Teachers also need to direct students to research and 
consider multiple possible solutions to the given problem. Finally, teachers need to support students to generate and test solutions as the students learn to optimize solutions by revising those several times to obtain the best possible design (NGSS Lead States, 2013).

\section{Framework of the proposed study}

This study engaged preservice teachers in developing STEAM tasks in an inquiry process of connection; collaboration, communication and application using PBL approach in order to enhance preservice teachers' disposition and knowledge of STEAM integration (see Figure 1).

As demonstrated in Figure 1, in Step 1, preservice first learn about STEAM integration, resources and materials in connected content areas of STEAM. They identify math and science skills and concepts in STEAM-related topics in CCSSM and NGSS standards, align these skills and concepts with appropriate grade levels, and understand the connections across content areas. In Step 2, they collaborate with their peers using the PBL approach to design various STEAM tasks to engage children in solving real world application problems at K-8 levels. In Step 3, they share their STEAM tasks with the whole class online, present their tasks in the classroom, and provide feedback to their peer groups' STEAM tasks. In Step 4, they revise their STEAM tasks based on feedback from their peers, and apply the tasks in their fieldwork. By working with these inquired steps, preservice teachers will enhance their knowledge of STEAM integration and develop productive disposition. Importantly, their integration will improve students' learning outcomes in STEAM areas.

\section{Methods}

Research design

This project used a mixed-research design in data collection and analysis to examine the effects of using the STEAM integration on preservice teachers' disposition and knowledge.

\section{Subjects and site}

The participants were 52 preservice teachers at K- 8 in two mathematics methods classes in a higher education institution in southern California in Spring 2019. The mathematics methods

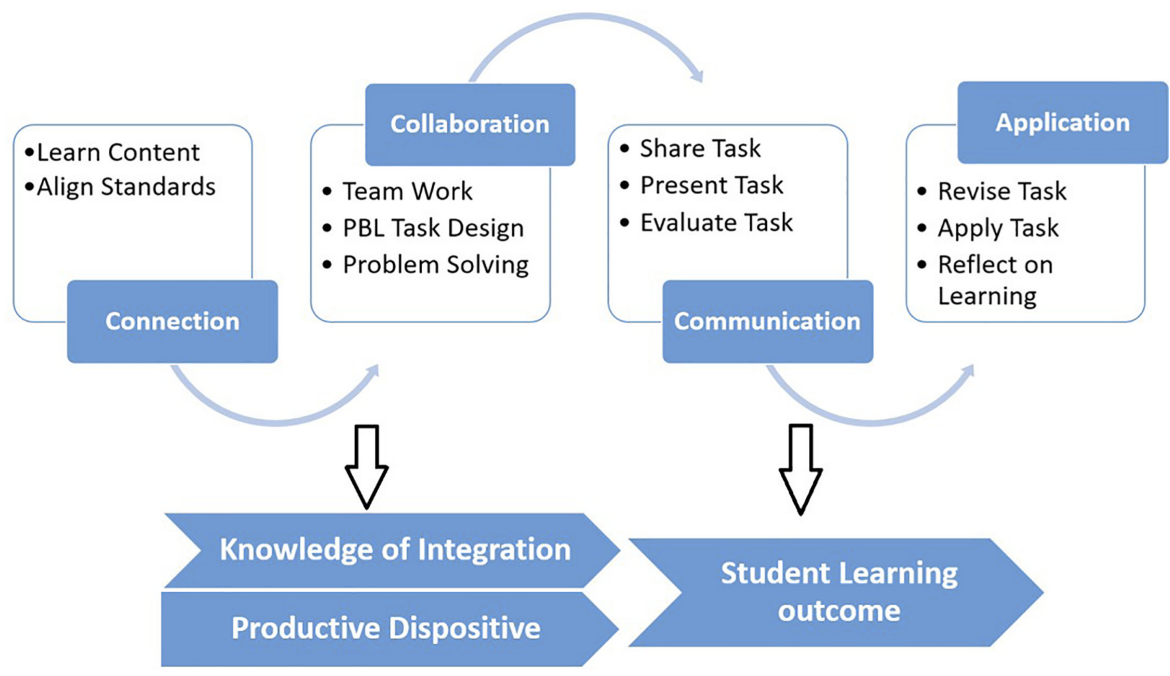

Figure 1.

Conceptual framework of effects on preservice teachers' the STEM integration 
JRIT 13,1

course was one of the required courses in the multiple subject credential program for K-8 preservice teachers.

\section{Procedure}

The preservice teachers in two mathematics methods classes in Spring 2019 participated in STEAM learning and development in the inquiry process of four steps of STEAM integration as addressed in Figure 1. Some preservice teachers also participated and shared their STEAM tasks at the 2019 Math at the Beach, which is the annual math education event with series of workshops for local school teachers and preservice teachers. The preservice teachers were asked to include the following main components in their STEAM task design: (1) CCSSM and MP Standards, NGSS and SEP Standards and student learning objectives; (2) Materials needed with the description and pictures; (3) Description of the STEAM task; (4) Teaching and learning strategies; (5) Directions with step by step procedures in five steps of the engineering design process: ask, design (art), build (engineering), test (science) and revise (finish product); (6) Worksheets for student activities in math and science; (7) Examples and pictures of the process and final product; (8) Description of the integration among math, science, engineering, technology and arts and (9) Assessment and closure.

\section{Data collection}

Pre- and postquestionnaires on teachers' knowledge and disposition were provided to assess the changes of the preservice teachers' knowledge and disposition toward teaching mathematics and integrating STEAM at the beginning and end of the semester, respectively. A total of 33 STEAM tasks developed by the preservice teachers were collected in the PowerPoint forms.

\section{Instrumentation}

Eight questions related to attitude, confidence, belief and knowledge of STEAM integration in teaching were designed by the author in the pre- and postquestionnaires, two questions in each of the four areas. 5-point Likert scale questions were used for these questions to measure preservice teachers' disposition and knowledge of STEAM integration. Cronbach's alpha shows reliability statistics as 0.694 for these items. The pre- and postquestions had similar questions, but one open-ended question about learning from the STEAM integration was added to the postquestionnaire: Describe your learning from doing STEAM project: (1) Learning from designing the STEAM Project, (2) Learning from peer group sharing the STEAM Project and (3) Learning from attending and/or presenting the STEAM tasks at 2019 Math at the Beach.

\section{Data analysis}

The data were analyzed using both quantitative and qualitative methods. The $t$-tests were used for the eight questions related to attitude, confidence, belief and knowledge of STEAM integration to find out the differences prior and after the STEAM integration to answer research question 1 . The Pearson correlation tests were used to answer research question 2 to find out the relationship between preservice teachers' disposition and knowledge of STEAM integration. Qualitative data analysis was used for the open-ended question about learning from the STEAM integration to answer research question 3. A total of 33 STEAM tasks were analyzed in three aspects at grade levels of K-2, 3-5 and 6-7: (1) Common topics, (2) Connection between CCSSM and NSGG content standards and (3) Connection between the CCSSMP and NGSS SEP standards. 


\section{Results}

The results of data analysis on the responses from the pre- and post-questionnaires, and on the STEAM tasks show that there was significant differences in pre-service teachers' attitude, confidence, and STEAM integration. There was also a positive correlation between attitude and STEAM integration, and between confidence and STEAM integration. The preservice teachers were able to design a variety of innovative STEAM tasks in real world applications. They were also able to smoothly connect the NGSS and CCSSM standards at different grade levels in their STEAM tasks. As the results, they learned a lot in teaching and learning with STEAM integration.

\section{Difference in attitude, confidence, belief and knowledge of STEAM integration}

To compare differences in attitude, confidence, belief and knowledge of STEAM integration between prior and after the STEAM integration, the paired samples $t$-tests were used to compare differences in the responses from the pre- and postquestionnaires. Table 1 below illustrates the results of the $t$-tests; there were significant differences in attitude $(t=-4.991$, $p=0.000)$, confidence $(t=-4.017, p=0.000)$, STEAM belief $(t=-2.681, p=0.010)$ and STEAM integration $(t=-13.714, p=0.000)$ between the pre- and postquestionnaires.

The differences in mean scores in attitude, confidence, belief and knowledge of STEAM integration between the pre- and postquestionnaires are also highlighted in Table 2. As shown in Figure 1, the preservice teachers' knowledge in STEAM in the postquestionnaire reported significantly high than it in the prequestionnaire. The differences in attitude and confidence between the prequestionnaire and postquestionnaire are also highlighted in Figure 2.

\section{Preservice teachers' learning from STEAM integration}

The results of analyzing the responses from the preservice teachers on their postquestionnaires show that the participants overall demonstrated a great deal of learning from doing the STEAM tasks. A common view among the preservice teachers $(55 \%)$ was that there are multiple ways to design a STEAM project that can be easily incorporated to the curriculum at little costs to teachers. Some $(42 \%)$ felt that it is a fun and engaging way for students to work collaboratively, creatively and critically by learning math and science all at the same time, while others $(33 \%)$ considered that through STEAM projects students are able to not only critically apply mathematical concepts, they are also able to apply them through hands on experiences and to real-life concepts. About $32 \%$ said that they learned how to work together as a team from doing the STEAM task and "It was interesting to learn from other peers their ideas and share them together as future educators." Another preservice teacher who echoed this view, "From peer group sharing I learned that STEAM projects can be effectively done at all grade levels." A small number of preservice teachers mentioned the importance of STEAM integration for special educational students. For example, one participant indicated, "I enjoyed learning that students with disabilities can also participate in such extra curricula's and that is important to allow them to feel a part of something so unique and exciting."

The following quotes are examples of the responses from two preservice teachers on their three aspects of learning from doing the STEAM tasks:

Pre-service teacher 1: I loved not only making the lesson but also presenting my STEAM project. It allowed me to learn how to effectively engage students in acquiring new skills in multiple subjects at one time. This is very helpful moving forward considering teachers are short on time in the classroom. I learned there are many resources from the presenters at Math at the Beach and there are opportunities to expand these projects beyond the classroom. I enjoyed learning that students with disabilities can also participate in such extra curricula's and that is important to allow them to feel a 


\section{JRIT \\ 13,1}

\section{4}

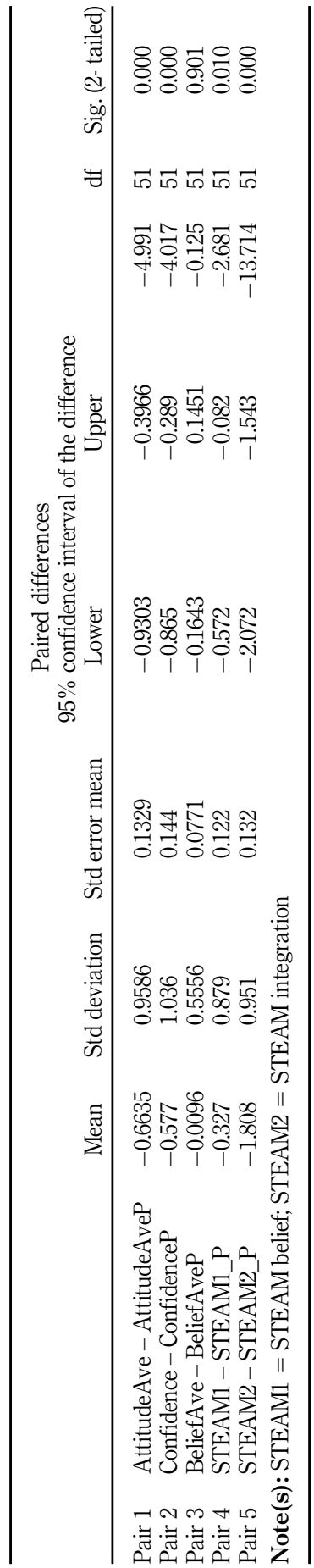

Table 1.

Paired samples test for disposition and knowledge between the pre- and postquestionnaires 
part of something so unique and exciting. In class, I found the other groups' presentations to be cute and educational as well. There are numerous activities that I would love to bring to my future classroom that could enrich their learning.

Pre-service teacher 2: What I learned from designing a STEAM Project is that it will take a lot of time and organization from the teacher. Next that a teacher should try to do it first, work out all the minor or major issues before instructing others to do it. 2) I learned that there are plenty of STEAM Projects that will attract student's attention for the project. I learned there are multiple components that students can learn from a project. Lastly, I learned that students look forward to working together during these projects.

\section{Impact of STEAM integration}

\section{Relationship between disposition and knowledge of STEAM integration}

As Table 3 shows, there was a positive correlation between attitude and confidence $(r=0.890)$, and between belief in learning math and importance of STEAM $(r=0.423)$ in the prequestionnaire.

\begin{tabular}{llllcc}
\hline & & & Paired samples statistics & \\
& & Mean & $N$ & Std. deviation & Std. error mean \\
\hline Pair 1 & AttitudeAve & 2.913 & 52 & 0.9788 & 0.1357 \\
& AttitudeAveP & 3.577 & 52 & 1.1648 & 0.1615 \\
Pair 2 & Confidence & 3.00 & 52 & 1.103 & 0.153 \\
& ConfidenceP & 3.58 & 52 & 1.161 & 0.161 \\
Pair 3 & BeliefAve & 4.663 & 52 & 0.5022 & 0.0696 \\
& BeliefAveP & 4.673 & 52 & 0.4415 & 0.0612 \\
Pair 4 & STEAM1 & 4.35 & 52 & 0.883 & 0.122 \\
& STEAM1_P & 4.67 & 52 & 0.617 & 0.086 \\
Pair 5 & STEAM2 & 2.62 & 52 & 0.889 & 0.093 \\
& STEAM2_P & 4.42 & 52 & 0.667 &
\end{tabular}

Note(s): STEAM1 = STEAM belief; STEAM2 = STEAM integration

Table 2.

Descriptive statistics of disposition and knowledge between the pre- and postquestionnaires

\section{Pre_\& Post Disposition}

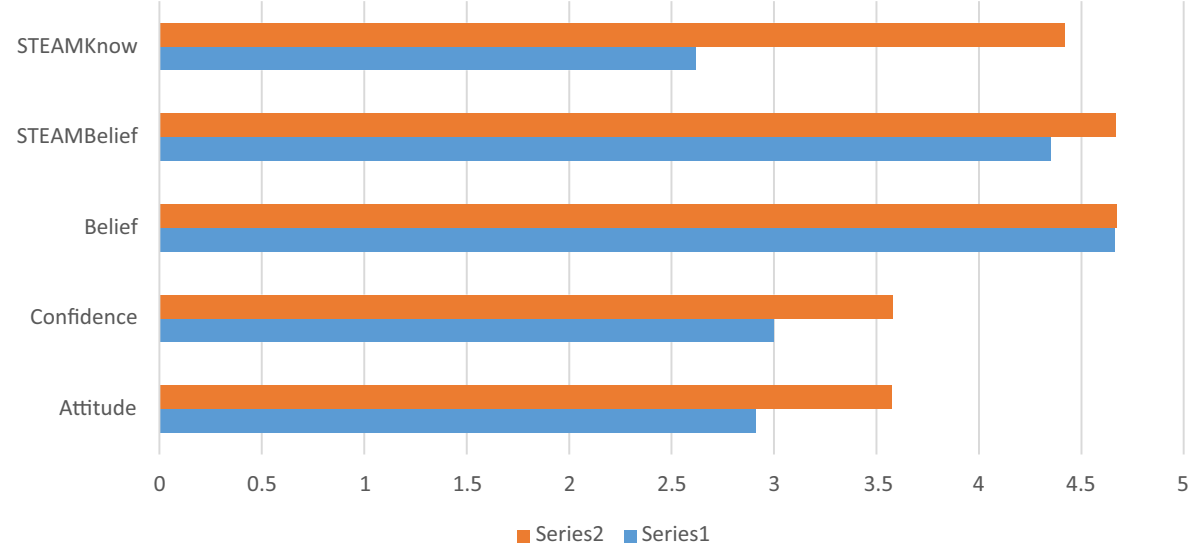

Figure 2.

Difference in attitude, confidence, belief and knowledge of STEAM integration between the pre- and postquestionnaires 


\section{JRIT 13,1}

\begin{tabular}{|c|c|c|c|c|c|c|}
\hline & & AttitudeAve & BeliefAve & Confidence & STEAM1 & STEAM2 \\
\hline \multirow[t]{3}{*}{ AttitudeAve } & Pearson correlation & 1 & 0.099 & $0.890^{* *}$ & -0.180 & 0.062 \\
\hline & Sig. (2-tailed) & & 484 & 000 & 0.201 & 0.660 \\
\hline & $N$ & 52 & 52 & 52 & 52 & 52 \\
\hline \multirow[t]{3}{*}{ BeliefAve } & Pearson correlation & 0.099 & 1 & 0.142 & $0.423^{* *}$ & 0.034 \\
\hline & Sig. (2-tailed) & 0.484 & & 0.316 & 0.002 & 0.812 \\
\hline & $N$ & 52 & 52 & 52 & 52 & 52 \\
\hline \multirow[t]{3}{*}{ Confidence } & Pearson correlation & $0.890^{* *}$ & 0.142 & 1 & -0.040 & 0.040 \\
\hline & Sig. (2-tailed) & 0.000 & 0.316 & & 0.777 & 0.778 \\
\hline & $N$ & 52 & 52 & 52 & 52 & 52 \\
\hline \multirow[t]{3}{*}{ STEAM1 } & Pearson correlation & -0.180 & $0.423^{* *}$ & -0.040 & 1 & 0.073 \\
\hline & Sig. (2-tailed) & 0.201 & 0.002 & 0.777 & & 0.607 \\
\hline & $N$ & 52 & 52 & 52 & 52 & 52 \\
\hline \multirow[t]{3}{*}{ TTEAM2 } & Pearson correlation & 0.062 & 0.034 & 0.040 & 0.073 & 1 \\
\hline & Sig. (2-tailed) & 0.660 & 0.812 & 0.778 & 0.607 & \\
\hline & $N$ & 52 & 52 & 52 & 52 & 52 \\
\hline
\end{tabular}

Table 3.

Correlation between disposition and knowledge of STEAM integration in prequestionnaire

Note(s): **Correlation is significant at the 0.01 level (2-tailed)

Interestingly, the most striking result to emerge from the postquestionnaire data is that there were not only a positive correlation between belief in learning math and importance of STEAM $(r=0.391)$ but also a positive correlation between attitude and knowledge of STEAM $(r=0.336)$, a positive correlation between confidence and knowledge of STEAM integration $(r=0.337)$, and a positive correlation between belief in importance of STEAMand knowledge of STEAM integration $(r=0.485)$ in the postquestionnaire (see Table 4 ).

\section{Common topics in STEAM tasks}

The results of analyzing the topics of STEAM tasks, as shown in Table 5, indicate that the preservice teachers focused on more visual representations for K-2 graders; they did more building tasks for grades 3-4; and they designed more STEAM tasks related to environment science for grades $5-7$.

Table 4.

Correlation between disposition and knowledge of STEAM integration in postquestionnaire

\begin{tabular}{llccccc}
\hline & AttitudeAve & BeliefAve & Confidence & STEAM1 & STEAM2 \\
\hline \multirow{2}{*}{ AttitudeAveP } & Pearson correlation & 1 & $0.996^{* *}$ & 0.202 & -0.005 & $0.336^{*}$ \\
& Sig. (2-tailed) & 52 & 0.000 & 0.150 & 0.971 & 0.015 \\
& $N$ & 52 & 52 & 52 & 52 \\
ConfidenceP & Pearson correlation & $0.996^{* *}$ & 1 & 0.203 & -0.005 & $0.337^{*}$ \\
& Sig. (2-tailed) & 0.000 & & 0.149 & 0.970 & 0.015 \\
& $N$ & 52 & 52 & 52 & 52 & 52 \\
BeliefAveP & Pearson correlation & 0.202 & 0.203 & 1 & $0.391^{* *}$ & 0.246 \\
& Sig. (2-tailed) & 0.150 & 0.149 & & 0.004 & 0.079 \\
& $N$ & 52 & 52 & 52 & 52 & 52 \\
STEAM1_A & Pearson correlation & -0.005 & -0.005 & $0.391^{* *}$ & 1 & $0.485^{* *}$ \\
& Sig. (2-tailed) & 0.971 & 0.970 & 0.004 & & 0.000 \\
& $N$ & 52 & 52 & 52 & 52 & 52 \\
STEAM2_A & Pearson correlation & $0.336^{*}$ & $0.337^{*}$ & 0.246 & $0.485^{* *}$ & 1 \\
& Sig. (2-tailed) & 0.015 & 0.015 & 0.079 & 0.000 & 52 \\
& $N$ & 52 & 52 & 52 & 52 & 52 \\
Note(s): **Correlation is significant at the 0.01 level (2-tailed) & & & \\
*Correlation is & significant at the 0.05 level (2-tailed) & & & & \\
& & & & & &
\end{tabular}




\begin{tabular}{|c|c|c|c|c|c|c|}
\hline Grade & Project name & Grade & Project name & Grade & Project name & Impact of \\
\hline K & Roller Coasters & 3 & $\begin{array}{l}\text { Spaghetti-Marshmallow } \\
\text { Tower }\end{array}$ & 5 & 3 Little Pigs & integration \\
\hline 1 & Geometric Shapes & 3 & What!!! It's a Water Slide & 5 & It is all in the STEAM! & \\
\hline 1 & $\begin{array}{l}\text { SHAPES First } \\
\text { Grade }\end{array}$ & 3 & Homemade Pan Flutes & 5 & Ball Launcher Challenge! & \\
\hline 2 & $\begin{array}{l}\text { Marshmallow } \\
\text { Catapult }\end{array}$ & 3 & Air Resistance Egg Drop & 5 & The Catapult Project & 37 \\
\hline 2 & Spiral Stick Art & 3 & Scribble Bot & 5 & What is Energy? & \\
\hline 2 & $\begin{array}{l}\text { STEAM } \\
\text { Integration Task }\end{array}$ & 3 & Hopper Popper & 5 & Biodegradation & \\
\hline \multirow[t]{10}{*}{2} & $\begin{array}{l}\text { Build a Boat } \\
\text { Challenge }\end{array}$ & 3 & Rubber Band Car & 5 & Sweet and Salty & \\
\hline & & 3 & Bottle Biome & 6 & Building a Balloon Car & \\
\hline & & 3 & What is the Wind Speed & 6 & Building Earthquake- & \\
\hline & & & Today? & & Resistant Structures & \\
\hline & & & $\begin{array}{l}\text { Wind Power! Designing a } \\
\text { Wind Turbine }\end{array}$ & 6 & Water Bottle Rockets & \\
\hline & & 4 & Thermometer & 7 & Thermometer & \\
\hline & & 4 & Cup Towers & & & \\
\hline & & 4 & Building Boats & & & Table \\
\hline & & 4 & Build On! & & & Topics of STEAM \\
\hline & & 4 & The Three Little Pigs & & & projects for grades $\mathrm{K}-7$ \\
\hline
\end{tabular}

Connection between science, engineering and math content standards in STEAM tasks

From Table 6, it can be seen that every grade level of the STEAM tasks in this study were related to the standards of Engineering, Technology and Applications of Science(ETS). In the engineering content areas, the preservice teachers linked their STEAM tasks to matter and its interaction at K-2 levels, to Motion and Stability, Earth System, Energy and Ecosystems at grades 3-5 levels, and to Energy, Earth's System Earth and Human Activity at grades 6-7 levels. About $58 \%$ of the STEAM tasks were at the grades 3-5 levels; grades K-2 levels had only $15 \%$ and grades $6-7$ levels had $27 \%$ of the STEAM tasks.

\section{Connection between CCSSMP and NGSS SEP practice standards in STEAM tasks}

As Table 7 shows, the CCSSMP standards used by the preservice teachers were varied: CCSSMP5 using appropriate tool strategically (22\%), CCSSMP1 make sense of problems and persevere in solving them (14\%) and CCSSMP6 attend to precision (13\%). The NGSS SEP standards used by the preservice teachers were diverse too: SEP3 Planning and carrying out investigations (24\%), SEP2 Developing and using models (19\%) and SEP1 Asking questions (for science) and defining problems (for engineering) (17\%).

\section{Discussion and conclusion}

The results in this study show that the STEAM integration in the mathematics methods courses engaged preservice teachers in the four steps of the inquiry process of connection, collaboration, communication and application for the STEAM integration using the PBL approach. The preservice teachers not only enhanced their disposition in attitude and confidence but also enhanced their belief and knowledge of STEAM integration.

\section{Effects on productive dispositions of STEAM integration}

The results of this study indicated that when providing an opportunity to engage preservice teachers in a fun and meaningful learning of STEAM integration, their disposition will be 
JRIT 13,1 changed. Interestingly, prior to the integration, there was only a positive correlation between attitude and confidence and between belief in learning math and importance of STEAM. After their learning and developing STEAM tasks, the more surprising positive correlation was with the attitude and knowledge of STEAM, and with confidence and knowledge of STEAM. These findings are supported by research studies that preservice teachers are more

\section{8}

Table 6.

Connection between NGSS, ETS and CCSSM standards in the STEAM tasks

\begin{tabular}{|c|c|c|c|c|c|}
\hline $\begin{array}{l}\text { Grade } \\
\text { level }\end{array}$ & $\%$ & $\begin{array}{l}\text { ETS } \\
\text { standards }\end{array}$ & Engineering content & $\begin{array}{l}\text { Science } \\
\text { standards }\end{array}$ & $\begin{array}{l}\text { CCSSM content } \\
\text { standards }\end{array}$ \\
\hline $\mathrm{K}-2$ & 15 & $\begin{array}{l}\text { K-2-ETS1-1 } \\
\text { K-2-ETS1-2 }\end{array}$ & Matter and its interactions & $\begin{array}{l}\text { K-PS2-2 } \\
\text { 1-PS4-4 } \\
\text { 1-PS4-2 } \\
\text { K-PS2-2 } \\
\text { 2-PS1-3 } \\
\text { 2-PS1-3 }\end{array}$ & $\begin{array}{l}\text { K.CC.B.4; } \\
\text { K.CC.B.4.A } \\
\text { 1.G.A.1, 1.G.A.2 } \\
\text { 3.G.A.1-2; } \\
\text { 2.NBT.A.1a } \\
\text { 2.MD.A.1; 2.MD.9 }\end{array}$ \\
\hline $3-5$ & 58 & $\begin{array}{l}\text { 3-5-ETS1-1 } \\
\text { 3-5-ETS1-2 } \\
\text { 3-5-ETS1-3 }\end{array}$ & $\begin{array}{l}\text { (1) Motion and stability forces and } \\
\text { interactions } \\
\text { (2) From molecules to organism: } \\
\text { structures and process } \\
\text { (3) Earth system } \\
\text { (4) Energy ecosystems: interactions, } \\
\text { energy, and dynamics }\end{array}$ & $\begin{array}{l}\text { 3-PS-2-1 } \\
\text { 3-PS-2-2 } \\
\text { 3.PS2.A } \\
\text { 3-LS1-1 } \\
\text { 4-ESS2-1 } \\
\text { 4-ESS2-2 } \\
\text { 4-PS3-4 } \\
\text { 4-PS3-2 } \\
\text { 5-LS2 }\end{array}$ & $\begin{array}{l}\text { 3.G.A.1, 3.G.A.2 } \\
\text { 3.MD.D.8; } \\
\text { 3.MD.B.4; } \\
\text { 3.MD.B.3 } \\
\text { 3.MD.A.1, } \\
\text { 3.MD.A.2; } \\
\text { 3.OA.A.2 } \\
\text { 4.NBT.B.5, } \\
\text { 4.NBT.B.5 } \\
\text { 4.GA.3; 4.MD.A.1 } \\
\text { 4.G.A.1, 4.G.A.2; } \\
\text { 4.G.1, } \\
\text { 4.G.3 } \\
\text { 4.MD.A.1, } \\
\text { 4.MD.A.2 } \\
\text { 5.G.A.1-2, 5.G.B.1-2 } \\
\text { 5.MD.A1; 5.G.3, } \\
\text { 5.G.4 } \\
\text { 6.G.4 }\end{array}$ \\
\hline $6-7$ & 27 & $\begin{array}{l}\text { MS-ETS1-4 } \\
\text { MS-ETS1-4 }\end{array}$ & $\begin{array}{l}\text { (1) Energy } \\
\text { (2) Earth's system } \\
\text { (3) Earth and human activity }\end{array}$ & $\begin{array}{l}\text { MS-PS3-5 } \\
\text { MS-ESS2-6 } \\
\text { MS-ESS3-2 }\end{array}$ & 6.SP.B.5 \\
\hline
\end{tabular}

\begin{tabular}{lrrlr}
\hline Standards & CCSSMP standards & $\%$ & NGSS SEP standards & $\%$ \\
\hline 1 & $\begin{array}{l}\text { Make sense of problems and } \\
\text { persevere in solving them }\end{array}$ & 14 & $\begin{array}{l}\text { Asking questions (for science) and 17 } \\
\text { defining problems (for engineering) }\end{array}$ & 17 \\
2 & $\begin{array}{l}\text { Reason abstractly and quantitatively } \\
\text { Construct viable arguments and } \\
\text { critique the reasoning of others }\end{array}$ & 12 & Developing and using models & 19 \\
3 & 11 & Planning and carrying out investigations & 24 \\
4 & Model with mathematics & Analyzing and interpreting data & 9 \\
5 & Use appropriate tools strategically & 22 & Using mathematics and computational & thinking \\
6 & 13 & $\begin{array}{l}\text { Constructing explanations (for science) and } \\
\text { designing solutions(for engineering) }\end{array}$ & 10 \\
7 & Attend to precision & 11 & Engaging in argument from evidence & 2 \\
8 & Look for and make use of structure & Obtaining, evaluating, and communicating & 2 \\
& Look for and express regularity in & 3 & information & \\
& repeated reasoning & & &
\end{tabular}

Look for and express regularity in

\section{Table 7.}

Connection between CCSSMP and NGSS SEP practice standards 8 in STEAM tasks 
confident in their knowledge and competent in their ability in integrating STEM in their future classrooms when they are given the opportunity to experience STEM content both as a student and a teacher (Berlin and White, 2012; Murphy and Mancini-Samuelson, 2012). An et al. (2014) indicated that interdisciplinary learning approach can improve students' motivation and engagement in learning. ISTE (2018) also calls for building the confidence and competency of educators to put technology standards for students and educators into practice.

\section{Impact of STEAM integration}

\section{Effects on knowledge of design STEAM curriculum}

The current study found that preservice teachers were able to develop different topics of STEAM tasks in diverse content standards of CCSSM and NGSS. It is interesting to note that in all STEAM tasks, the preservice teachers were able to use the standards of ETS and engineering content standards. They were also able to connect these NGSS standards to the CCSSM content standards. As indicated in the theoretical framework, the engineering design process is the key step in STEAM integration (NGSS Lead States, 2013). It develops problemsolving skills and engage students in an authentic learning process (NCTM, 2014). Another important finding was that some preservice teachers were able to develop children's capacities in planning and carrying out investigations (NGSS SEP3), using appropriate tools strategically (CCSSMP5), and developing and using models (NGSS SEP2) in their STEAM tasks. The most interesting finding was that some preservice teachers used CCSSMP1 make sense of problems and persevere in solving them, and CCSSMP6 attend to precision in their STEAM tasks, which are the new focuses in CCSSMP standards (NGACBP \& CCSSO, 2010).

\section{New learning from STEAM integration}

The most obvious learning from the STEAM integration in this study is that more preservice teachers now realized that there are multiple ways to design STEAM projects and they can be easily incorporated to the curriculum. They also recognized that STEAM task is a fun and engaging way for students to work collaboratively, creatively and critically by learning math and science all at the same time. In addition, they learned more ideas and strategies of STEAM from teamwork, sharing, presenting and applying (National Academy of Science, 2018). The teamwork allowed them to collaborate, analyze, design, develop, implement and evaluate their shared curriculum (Huizinga et al., 2015). The four steps of engaging preservice teachers in designing interdisciplinary curriculum provide opportunities for their professional growth and challenge them to alter their current perspectives of curriculum and subject matter (Trinter and Hope, 2016).

In conclusion, this study set out to investigate the effects of STEAM integration on preservice teachers' disposition and knowledge. The results of this study indicate that using math methods courses to engage preservice teachers in learning STEAM integration and designing authentic STEAM tasks in four steps enhanced preservice teachers' attitude, confidence and belief that significantly related to their knowledge of STEAM integration. The results of this research support the idea that the STEAM education not only allow students to explore, create, analyze, discover and draw conclusions related to important application in everyday lives (Tran, 2018) but also allows preservice teachers to have earlier and more robust interdisciplinary teaching experiences that will help develop their PCK in integration (An, 2017; Doering et al., 2009). As supported by research studies, preservice teachers need to experience and visualize the integration in authentic classrooms with strategies and pedagogy learned from coursework (Abell, 2006; Burton, 2019). A further study could investigate the effects of engaging preservice teachers in learning, designing and applying STEAM integration in their fieldwork on children's learning outcomes as indicated in the conceptual framework in this study. 
JRIT 13,1
The following conclusions can be drawn from the present study that integrating STEAM components in mathematics methods fosters preservice teachers' creativity, connection, communication, application and teamwork skills. Importantly, it enhances K-8 pre-service teachers' productive dispositions and knowledge in STEAM integration. These findings have significant implications for the understanding of how to prepare future teachers in STEAM integration in higher education.

\section{References}

Abell, S.K. (2006), "Challenges and opportunities for field experiences in elementary science teacher preparation", in Appelton, K. (Ed.), Elementary Science Teacher Education: International Perspectives on Contemporary Issues and Practice, Lawrence Erlbaum, Mahwah, NJ, pp. 73-89.

An, S.A. (2017), "Preservice teachers' knowledge of interdisciplinary pedagogy: the case of elementary mathematics-science integrated lessons", ZDM Mathematics Education, Vol. 49 No. 2, pp. 237-248.

An, S.A., Tillman, D., Boren, R. and Wang, J. (2014), "Fostering elementary students' mathematics disposition through music-mathematics integrated lessons", International Journal for Mathematics Teaching and Learning, Vol. 15 No. 3, pp. 1-18.

An, S.A. and Tillman, D.A. (2018), "Preservice teachers' pedagogical use of 'gerrymandering' to integrate social studies and mathematics", Journal of Mathematics Education, Vol. 11 No. 3, pp. 33-53.

Belliveau, G. (2007), "An alternative practicum model for teaching and learning”, Canadian Journal of Education, Vol. 30 No. 1, pp. 47-67.

Berlin, D.F. and White, A.L. (2012), "A longitudinal look at attitudes and perceptions related to the integration of mathematics, science, and technology education", School Science and Mathematics, Vol. 112 No. 1, pp. 20-30.

Binkhorst, F., Handelzalts, A., Poortman, C. and van Joolingen, W. (2015), "Understanding teacher design teams - a mixed methods approach to developing a descriptive framework", Teaching and Teacher Education, Vol. 51, pp. 213-224.

Brown, J. (2012), "The current status of STEM education research", Journal of STEM Education, Vol. 13 No. 5, pp. 7-11.

Burton, M. (2019), "Teaching mathematics: multiple perspectives among teacher candidates during a STEM field experience", Journal of Mathematics Education, Vol. 12 No. 1, pp. 90-106.

Bybee, R.W. (2010), "Advancing STEM education: a 20/20 vision”, Technology and Engineering Teacher, Vol. 70, No. 1, pp. 30-34.

California Department of Education (2019a), "STEM education in California", available at: https:// www.cde.ca.gov/pd/ca/sc/stemintrod.asp.

California Department of Education (2019b), “Test results for California's assessment", available at: https://caaspp-elpac.cde.ca.gov/caaspp/.

Carnevale, A., Melton, M. and Smith, N. (2011), STEM State-Level Analysis, Georgetown University Center on Education and the Workforce, Washington, DC.

Chen, G. (2015), "10 major challenges facing public schools", available at: https://www.linkedin.com/ pulse/10-major-challenges-facing-public-schools-debbie-hilbish.

DiFrancesca, D., Lee, C. and McIntyre, E. (2014), "Where is the 'E' in STEM for young children? Engineering design education in an elementary teacher preparation program", Issues in Teacher Education, Vol. 23 No. 1, pp. 49-64.

Doering, A., Veletsianos, G., Scharber, C. and Miller, C. (2009), "Using the technological, pedagogical, and content knowledge framework to design online learning environments and professional development", Journal of Educational Computing Research, Vol. 41 No. 3, pp. 319-346. 
Han, S., Capraro, R. and Capraro, M.M. (2015), "How science, technology, engineering, and mathematics (STEM) project-based learning (PBL) affects high, middle, and low achievers differently: the impact of student factors on achievement", International Journal of Science and Mathematics Education, Vol. 13 No. 5, pp. 1089-1113.

Huizinga, T., Handelzalts, A., Nieveen, N. and Voogt, J.M. (2015), "Fostering teachers' design expertise in teacher design teams: conducive design and support activities", The Curriculum Journal, Vol. 26 No. 1, pp. 137-163.

ISTE (2007), National Educational Technology Standards for Students, Author, Eugene, OR.

ISTE (2017), "ISTE standards for teachers", available at: http://www.iste.org/standards/standards/ standards-for-teachers.

ISTE (2018), "ISTE standards for education leaders", available at: https://id.iste.org/docs/StandardsResources/iste-standards-edleaders_v3.pdf.

Koehler, M.J. and Mishra, P. (2009), "What is technological pedagogical content knowledge?", Contemporary Issues in Technology and Teacher Education, Vol. 9 No. 1, pp. 60-70.

Murphy, T.P. and Mancini-Samuelson, G.J. (2012), "Graduating STEM competent and confident teachers: the creation of a STEM certificate for elementary education majors", Journal of College Science Teaching, Vol. 42 No. 2, p. 18.

Nadelson, L.S. and Seifert, A. (2013), "Perceptions, engagement, and practices of teachers seeking professional development in place-based integrated STEM", Teacher Education and Practice, Vol. 26 No. 2, pp. 242-265.

National Academies of Science, Engineering, and Medicine (2018), "Policy and global affairs, board on higher education and workforce", Planning Committee for the National Summit on Developing a STEM Workforce Strategy, Joe Alper, Rapporteur.

National Center for Education Statistics (2015a), "Welcome to TIMSS and TIMSS advanced results from 2015”, available at: https://nces.ed.gov/timss/timss2015/.

National Center for Education Statistics (2015b), "Welcome to PISA 2015 results”, available at: https:// nces.ed.gov/surveys/pisa/pisa2015/index.asp.

National Center for Education Statistics (2018), "PISA 2018 US results”, available at: https://nces.ed. gov/surveys/pisa/pisa2018/\#/.

National Council of Teachers of Mathematics (2014), Principles to Action: Ensuring Mathematical Success for All, NCTM, Reston, VA.

National Governors Association Center for Best Practices, Council of Chief State School Officers (2010), Common Core State Standards for Mathematics, National Governors Association Center for Best Practices, Council of Chief State School Officers, Washington, DC.

National Research Council (2011), Successful K-12 STEM Education: Identifying Effective Approaches in Science, Technology, Engineering, and Mathematics, National Academies Press, Washington, DC.

NGSS Lead States (2013), Next Generation Science Standards: For States, by States, National Academies Press, Washington, DC, available at: https:/nces.ed.gov/surveys/pisa/pisa2015/ pisa2015highlights_1.asp.

Park, H., Byun, S., Sim, J., Han, H. and Baek, Y.S. (2016), “Teachers' perceptions and practices of STEAM education in South Korea", Eurasia Journal of Mathematics, Science and Technology Education, Vol. 12 No. 7, pp. 1739-1753. doi: 10.12973/eurasia.2016.1531a.

Savery, J.R. (2006), "Overview of problem-based learning: definitions and distinctions", Interdisciplinary Journal of Problem-Based Learning, Vol. 1 No. $1 .$.

Scott, C. (2012), "An investigation of Science, Technology, Engineering and Mathematics (STEM) focused high schools in the US", Journal of STEM Education, Vol. 13 No. 5, pp. 30-39.

Shaughnessy, M. (2013), "Mathematics in a STEM context", Mathematics Teaching in the Middle School, Vol. 18 No. 6, p. 324. 
JRIT

13,1

Sousa, D.A. and Pilecki, T. (2013), From STEM to STEAM: Using Brain-Cmpatible Strategies to Integrate the Arts, Corwin Press, Thousand Oaks, CA.

Tran, Y. (2018), “The development of elementary-aged students' STEM and computer science literacy in elementary perceptions and career aspirations in STEM", Technology, Knowledge and Learning, Vol. 23 No. 2, pp. 273-299.

Trinter, C.P. and Hope, S. (2016), "The absence and presence of mathematics in teacher-led, interdisciplinary unit design”, Journal of Mathematics Education, Vol. 9 No. 2, pp. 4-21.

Tsupros, N., Kohler, R. and Hallinen, J. (2009), STEM Education: A Project to Identify the Missing Components, Intermediate Unit 1 and Carnegie Mellon, Pittsburgh, PA.

Weiss, I.R., Banilower, E.R., McMahon, K.C. and Smith, P.S. (2001), 2000 National Survey of Science and Mathematics Education, Horizon Research, Chapel Hill, NC.

$\mathrm{Wu}, \mathrm{Z}$. and An, S. (2015), Teaching Elementary and Middle School Mathematics Using the MSA Approach: Model, Strategy, and Application, 2nd ed., Education for All Publisher, Irvine, CA.

\section{Corresponding author}

Shuhua An can be contacted at: shuhua.an@csulb.edu

For instructions on how to order reprints of this article, please visit our website:

www.emeraldgrouppublishing.com/licensing/reprints.htm

Or contact us for further details: permissions@emeraldinsight.com 